\title{
Rola aktywności fizycznej w leczeniu pacjentów z przewlekłą chorobą nerek
}

\section{The role of physical activity in patients with end stage renal disease}

\author{
Katarzyna Weber-Nowakowska1® ${ }^{\bowtie a g d a l e n a ~ G e ̨ b s k a 1, ~ M a r e k ~ M y s ́ l a k ², ~ E w e l i n a ~ Z ̇ y z ̇ n i e w s k a-B a n a s z a k, ~}$ \\ Monika Stecko ${ }^{3}$
}

${ }^{1}$ Pomorski Uniwersytet Medyczny w Szczecinie, Samodzielna Pracownia Fizjoterapii i Odnowy Biologicznej, ul. Żołnierska 48, 71-210 Szczecin

2 Pomorski Uniwersytet Medyczny w Szczecinie, Zakład Interwencji Klinicznych i Medycyny Katastrof, ul. Gen. Chłapowskiego 11, 70-103 Szczecin

${ }^{3}$ Pomorski Uniwersytet Medyczny w Szczecinie, Studium Doktoranckie Wydziału Nauk o Zdrowiu, ul. Żołnierska 54, 71-210 Szczecin

$\triangle$ katarzyna.weber@pum.edu.pl

\begin{abstract}
Constant improvements in treatment options for end stage renal disease leads to increasing numbers of patients qualified for renal transplantation. The best results are obtained with pre-emptive transplantation allowing avoidance of dialysis. The most common cause of death in patients awaiting kidney transplantation is cardiovascular disease. Every second dialysis death is a consequence of cardiovascular disease. Hypertension, atherosclerosis,
\end{abstract}

hyperlipidemia and obesity are commonly diagnosed. Numerous scientific studies confirm the positive effects of physical activity on reducing the risk of death from cardiovascular incident. The recommendation of moderate activity (adjusted to the ability of the patient) would improve the functioning of patients, and would have a substantial impact on the self-reported quality of life. Keywords: end stage renal disease; physical activity; rehabilitation; physiotherapy.

\begin{abstract}
ABSTRAKT
Ciągłe doskonalenie metod leczenia pacjentów ze schyłkową niewydolnością nerek powoduje, że stale powiększa się grupa chorych zakwalifikowanych do operacji przeszczepienia narządu. Najkorzystniejsze jest wykonanie zabiegu wyprzedzającego, pozwalającego uniknąć hemodializoterapii. Najczęstszą przyczyną zgonów w grupie pacjentów oczekujących na transplantację nerki są choroby układu sercowo-naczyniowego. Obecnie co drugi zgon dializowanego pacjenta jest następstwem choroby układu krążenia. Powszechnie diagnozowane są: nadciśnienie tętnicze, miażdżyca, hiperlipidemia czy otyłość. Liczne badania potwierdzają pozytywny wpływ aktywności fizycznej
\end{abstract}

na zmniejszenie ryzyka zgonu z powodu incydentu kardiologicznego. Zalecenie umiarkowanej aktywności (dostosowanej do możliwości chorego) przyczyniłoby się do poprawy funkcjonowania chorych, przyspieszyłoby powrót do sprawności po zabiegu transplantacji oraz miałoby niebagatelny wpływ na subiektywną ocenę jakości życia.

Pomimo istnienia doniesień naukowych ukazujących pozytywny wpływ rehabilitacji na stan zdrowia pacjentów z przewlekłą niewydolnością nerek, nie jest ona powszechnie wprowadzana do programów leczenia.

Słowa kluczowe: przewlekła niewydolność nerek; aktywność fizyczna; rehabilitacja; fizjoterapia.

\section{WSTĘP}

Do głównych przyczyn wystąpienia schyłkowego stadium przewlekłej choroby nerek (PChN) zalicza się: cukrzycową chorobę nerek, nefropatię nadciśnieniową, glomerulopatie wtórne i pierwotne, torbielowatość nerek i sródmiąższowe zapalenie nerek [1, 2]. Obecnie dostępne są dwa rodzaje leczenia PChN: dializoterapia oraz transplantacja narządu. Obie metody umożliwiają zastąpienie funkcji nerek u pacjentów w piątym stadium PChN.

W 2010 r. na całym świecie było ponad 2,5 mln osób korzystających z leczenia nerkozastępczego, a w Polsce ok. 25 tys. Dializoterapia to najczęściej stosowana metoda leczenia PChN. Liczba osób korzystających z tego typu terapii stale rośnie, co związane jest z rozpowszechnieniem tej metody w krajach rozwijających się [3]. Pomimo postępu nauk medycznych wciąż nie udaje się uniknąć wielu działań niepożądanych występujących podczas przewlekłej dializoterapii. Chorzy narażeni są na liczne odległe powikłania, będące następstwem długotrwałego leczenia nerkozastępczego. Chociaż na chorych dializowanych przeznaczany jest duży nakład finansowy oraz istnieje stała progresji możliwości leczenia nerkozastępczego, nadal stwierdza się istotną śmiertelność, chorobowość oraz obniżoną jakość życia wśród pacjentów ze schyłkową niewydolnością nerek. Najczęstszą przyczyną zgonów w tej grupie są choroby układu sercowo-naczyniowego. Obecnie co drugi zgon dializowanego pacjenta jest następstwem choroby układu krążenia [4]. Za główny czynnik uznaje się powikłania miażdżycy, której postęp jest zdecydowanie szybszy niż w ogólnej populacji. Oczywisty jest związek miażdżycy z takimi czynnikami ryzyka, jak: nadciśnienie tętnicze, cukrzyca, palenie tytoniu czy otyłość. Dodatkowo w grupie pacjentów z PChN 
występują zaburzenia wapniowo-fosforanowe, niedożywienie oraz przewlekły stan zapalny. Niemal $40 \%$ zgonów odnotowywanych w tej grupie spowodowanych jest schorzeniami mięśnia sercowego, w tym zawałem serca i jego powikłaniami [5]. U 3/4 pacjentów rozpoczynających dializoterapię rozpoznaje się przerost lewej komory serca, będącej istotnym czynnikiem ryzyka hospitalizacji oraz śmierci. Stan ten jest wywołany powszechnie występującym w tej grupie pacjentów przewodnieniem, nadciśnieniem tętniczym i niedokrwistością [6]. Dodatkowym istotnym czynnikiem ryzyka zgonu jest brak aktywności fizycznej powszechnie obserwowany wśród pacjentów poddawanych hemodializie i dializoterapii otrzewnowej.

Poddawani leczeniu nerkozastępczemu pacjenci, którzy spełniają odpowiednie kryteria, kwalifikowani są do zabiegu transplantacji narządu. W porównaniu z dializoterapią przeszczepienie nerki znacznie wydłuża czas życia i poprawia jego komfort, uwalniając pacjenta od konieczności przebywania w stacjach dializ czy systematycznego wykonywania procedur dializoterapii otrzewnowej, ponadto jest tańsze. Poza aspektem ekonomicznym istnieje wiele korzyści medycznych i społecznych, które przemawiają za wyższością transplantacji nad pozostałymi metodami leczenia nerkozastępczego. Istotny jest przytaczany w licznych publikacjach fakt, iż ryzyko śmierci wśród pacjentów dializowanych oczekujących na transplantacje jest o 68\% wyższe niż u osób poddanych temu zabiegowi [3]. Dłuższy czas dializoterapii przed transplantacją istotnie ujemnie wpływa na wynik leczenia [7]. Najlepsze wyniki leczenia obserwowane są u chorych, u których wykonano przeszczepienie wyprzedzające.

W celu kwalifikacji pacjenta do transplantacji lekarz prowadzący zobligowany jest do wykonania badań i konsultacji specjalistycznych wykluczających przeciwwskazania względne i bezwzględne. Do przeciwwskazań zaliczyć można: AIDS, aktywną chorobę nowotworową, uogólnioną miażdżycę, aktywne choroby infekcyjne, aktywne psychozy czy brak współpracy chorego [8]. Brak przeciwwskazań pozwala na umieszczenie pacjenta na Krajowej Liście Oczekujących na przeszczepienie narządu.

W ostatnich latach obserwowany jest stały wzrost liczby przeszczepień nerki w Polsce. Za koordynację przeszczepień w Polsce odpowiedzialne jest Centrum Organizacyjno-Koordynacyjne do Spraw Transplantacji „Poltransplant”. W 2015 r. przeszczepiono nerki łącznie 1017 biorcom. W tej grupie 60 osób otrzymało narząd od dawcy żywego, a 957 od dawców zmarłych [9]. Warto zaznaczyć, iż całkowita liczba osób oczekujących na transplantację wyniosła 2550 i w ostatnich latach utrzymuje się na podobnym poziomie (2014 r. - 2635 osób, 2013 r. - 2565, 2012 r. - 2683) [9]. Pomimo stałego wzrostu liczby potencjalnych dawców narządu jest ona wciąż niewystarczająca w stosunku do oczekujących biorców.

Należy pamiętać, że przeszczepienie narządu również niesie za sobą podwyższone ryzyko rozwoju chorób sercowo-naczyniowych. Ryzyko roczne wystąpienia zdarzenia sercowo-naczyniowego zakończonego zgonem wynosi 3,5-5\% i jest 50-krotnie większe niż w populacji ogólnej [10]. Do najczęściej stwierdzanych zaburzeń kardiologicznych u pacjentów po zabiegu transplantacji zalicza się: przerost lewej komory serca, kardiomiopatię, zastoinową niewydolność serca, chorobę niedokrwienną serca, nadciśnienie tętnicze czy cukrzycę potransplantacyjną $[11,12]$. Obserwowany wzrost liczby chorych oczekujących na transplantację powoduje, iż w najbliższym czasie tendencja ta nie ulegnie zmianie.

Wiedząc, że jest to grupa pacjentów wymagająca szczególnej opieki (liczne choroby współistniejące, wysokie ryzyko zgonu), należy zwrócić uwagę na rolę aktywności fizycznej i jej pozytywny wpływ na zmniejszenie ryzyka wystąpienia incydentów kardiologicznych, poprawę parametrów biochemicznych krwi czy redukcję masy ciała. Stały, odpowiednio dostosowany wysiłek fizyczny pozwoli na szybszy powrót do sprawności po zabiegu operacyjnym oraz do pełnionych funkcji społecznych.

Wyniki wielu badań potwierdzają, iż aktywność fizyczna jest jedną z metod prewencji chorób układu krążenia, zarówno występujących pierwotnie, jak i wtórnie u pacjentów z PChN [13]. Odpowiednio dostosowany wysiłek może bezpośrednio i pośrednio wpłynąć na ryzyko wystąpienia chorób kardiologicznych. Działanie bezpośrednie związane jest ze wzrostem napięcia nerwu błędnego i spowolnieniem akcji serca, co obniża prawdopodobieństwo pojawienia się arytmii komorowych. Oddziaływanie pośrednie wiąże się ze zmniejszeniem stężenia cholesterolu, wskaźników zapalnych i masy ciała, a zwiększeniem masy mięśniowej i poprawą insulinozależności tkanek obwodowych $[6,14]$. Regularne ćwiczenia fizyczne są obowiązkowo zalecane w przypadku leczenia otyłości, cukrzycy, insulinooporności. Prawdopodobieństwo wystąpienia tych chorób jest wysokie w grupie osób z PChN [15].

Przewlekła choroba nerek i wiążąca się z nią stała dializoterapia mają ogromny wpływ na tryb życia. Grupa osób leczonych nerkozastępczo charakteryzuje się niechęcią i lękiem do podejmowania aktywności fizycznej, preferowaniem siedzącego trybu życia oraz brakiem motywacji do wprowadzenia zmian w codziennym funkcjonowaniu. Niewątpliwie fakt, iż zabiegi hemodializy przeprowadzane są w pozycji leżącej, a pacjenci korzystający z tej formy leczenia spędzają w stacjach dializ ok. 800 godz. rocznie, ma znaczący wpływ na ich sposób funkcjonowania [16]. Rola aktywności fizycznej jest niedoceniana w pracy z tą grupą pacjentów, pomimo powszechnej wiedzy na temat negatywnego wpływu braku ruchu. Opisane czynniki ryzyka zgonu oraz choroby współistniejące, powszechnie diagnozowane w grupie pacjentów leczonych nerkozastępczo, znacząco wpływają na sprawność i wydolność fizyczną. Systematyczna aktywność ma niebagatelny wpływ na poprawę parametrów wydolnościowych, zwiększenie siły mięśniowej i normalizację wybranych parametrów biochemicznych. Oznacza to, że istnieje możliwość zmniejszenia ryzyka wystąpienia chorób sercowo-naczyniowych bądź w przypadku ich zdiagnozowania - zniwelowania następstw poprzez wprowadzenie systematycznej aktywności fizycznej.

Van Heuvelen i wsp. udowodnili, że zwiększenie poziomu aktywności fizycznej wpływa na poprawę sprawności fizycznej, zmniejszając ryzyko zaburzeń naczyniowo-sercowych [17]. 
W sytuacji wystąpienia konkretnych nieprawidłowości znaczącą rolę odgrywają odpowiednio opracowane i ukierunkowane działania rehabilitacyjne, uwzględniające zarówno problem główny, jak i choroby współistniejące. W przypadku osób ze schyłkową niewydolnością nerek należy ukierunkować działania na występujące zaburzenia układu krążenia, będące problemem zasadniczym, jak również przeciwdziałać zmniejszonej sile mięśniowej i dolegliwościom bólowym ze strony układu ruchu oraz obniżonej aktywności. Krawczyk i wsp. przeprowadzili badanie mające ocenić wpływ zwiększonej aktywności ruchowej na wybrane parametry gospodarki tłuszczowo-węglowodanowej w grupie pacjentów leczonych sanatoryjnie. Dwukrotnie (przed rozpoczęciem treningu i po 15 dniach jego trwania) oznaczono poziom glukozy we krwi oraz frakcje lipidowe. Uzyskano istotne statystycznie zmniejszenie stężenia glukozy, triglicerydów i cholesterolu całkowitego. Wykazano, iż systematyczna aktywność ruchowa wpływa normalizująco na wybrane parametry biochemiczne krwi [14].

Kolejnym istotnym czynnikiem zwiększającym ryzyko wystąpienia chorób kardiologicznych i metabolicznych są powszechnie występujące w tej grupie chorych nadwaga i otyłość. Obniżenie masy ciała wpływa korzystnie na parametry lipidowe, obniżenie wartości ciśnienia tętniczego krwi, stężenia glukozy oraz poprawia reakcję układu krążenia na wysiłek fizyczny. Otyłość zdecydowanie zwiększa ryzyko wystąpienia licznych powikłań, które niejednokrotnie prowadzą do zgonu.

W latach 1991-2004 naukowcy z Włoch i USA przeprowadzili badanie na 1102 biorcach nerki $[18,19]$. Celem pracy była ocena zależności pomiędzy wskaźnikiem masy ciała (BMI) a ryzykiem wystąpienia zaburzeń kardiologicznych takich jak: zastoinowa niewydolność serca, migotanie przedsionków i zawał mięśnia sercowego u osób poddanych zabiegowi transplantacji. Wszyscy uczestnicy charakteryzowali się zwiększoną wartością BMI. U 25\% BMI było większe od 30, co wskazywało na otyłość. Przed zabiegiem przeszczepienia narządu choroby układu sercowo-naczyniowego zdiagnozowano u 19,2\% badanych. Podczas 5-letniej obserwacji liczba rozpoznań powikłań kardiologicznych wzrosła w porównaniu do okresu przedtransplantacyjnego o 8,67-28,35\%, zależnie od wzrostu wartości BMI. Wykazano, że nieprawidłowa wartość BMI jest niezależnym czynnikiem ryzyka wystąpienia chorób układu sercowo-naczyniowego w badanej grupie. Segev i wsp., analizujący 132 353 zarejestrowanych w latach 1995-2006 w USA biorców nerki, wykazali związek pomiędzy otyłością a czasem oczekiwania na transplantację [20]. Wśród badanych nadwagę stwierdzono u 34,3\%, otyłość I stopnia u 19,3\%, II stopnia u 7,2\%, III stopnia u 2,7\%. Wykazano, że średni czas oczekiwania wzrastał w zależności od wartości BMI (40 miesięcy dla osób z nadwagą, 51 miesięcy dla osób z otyłością II stopnia i 59 miesięcy dla chorych z III stopniem otyłości). Pacjenci z wysokim BMI charakteryzowali się większym ryzykiem powikłań pooperacyjnych i śmiertelnością.

Założenie o potrzebie wprowadzenia aktywności fizycznej w grupie pacjentów z PChN potwierdzają wyniki badaczy z Uniwersytetu Medycznego w Warszawie [21]. Zaproponowali oni aktywnym biorcom nerki stosowanie autorskiego zestawu ćwiczeń. W jego skład wchodziły ćwiczenia wzmacniające mięśnie kończyn dolnych, górnych oraz mięśnie brzucha, ponadto ćwiczenia relaksacyjne i oddechowe, a po 6 miesiącach trening marszowy. Po roku oceniono wpływ przeprowadzonych działań. Stwierdzono wyraźną poprawę wzrostu siły mięśniowej oraz istotną statystycznie poprawę jakości życia. Zastosowany przez Chojak-Fijałkę i Smoleńskiego program treningowy w grupie pacjentów hemodializowanych również przyniósł znaczne zmiany w badanych przez nich parametrach: tolerancji wysiłku, sile mięśniowej kończyn dolnych oraz jakości życia [16]. W prowadzonych przez nich badaniach zastosowano 6-miesięczny trening fizyczny obejmujący ćwiczenia czynne wolne kończyn dolnych, jazdę na cykloergometrze rowerowym oraz ćwiczenia oddechowe. Pacjenci wykonywali zalecone działania podczas zabiegów hemodializoterapii. U wszystkich uczestników uzyskano wzrost siły mięśniowej kończyn dolnych (po 6 miesiącach o 57,12\%) oraz poprawę wyniku próby wysiłkowej (o 55,25\%). Istotną statystycznie poprawę osiągnięto w badaniu jakości życia oceniającym ogólną subiektywną ocenę zdrowia. Autorzy wysunęli wniosek, że prowadzenie treningu podczas zabiegu hemodializy jest rozwiązaniem korzystnym, skutecznym i dobrze tolerowanym.

W związku z wysokim prawdopodobieństwie śmierci z powodu chorób kardiologicznych w grupie osób oczekujących na przeszczepienie narządu i po przeprowadzonej transplantacji wprowadzenie programu treningowego wydaje się oczywiste. Edukacja pacjentów, przedstawienie czynników ryzyka oraz możliwości przeciwdziałania im poprzez odpowiednio dopasowany wysiłek fizyczny powinny być działaniami obligatoryjnymi.

W ostatniej dekadzie pojawiły się wyniki badań jednoznacznie wskazujące na pozytywny wpływ aktywności fizycznej na funkcjonowanie, powrót do sprawności i jakość życia pacjentów po transplantacji $[22,23]$. Pomimo tego wiedza i świadomość w tym zakresie są wciąż niewystarczająca. Personel medyczny rzadko zaleca systematyczną aktywność fizyczną pacjentom ze schyłkową niewydolnością nerek. Ćwiczenia nie są obowiązkowym elementem leczenia po zabiegu transplantacji. W 2003 r. podczas konferencji World Congress of Nephrology zapytano lekarzy nefrologów o ich stanowisko w kwestii roli aktywności fizycznej w procesie terapii osób ze schyłkową niewydolnością nerek. 95\% badanych stwierdziło, że siedzący tryb życia przyczynia się do zgonu w tej grupie pacjentów, 92\% jest świadomych korzystnego działania aktywności fizycznej, 78\% przychyla się do stwierdzenia, że to lekarz nefrolog powinien nakłaniać pacjentów do regularnych ćwiczeń. Tylko 32\% przyznało, że proponuje swoim pacjentom program rehabilitacji [5]. Siedzący tryb życia charakterystyczny dla osób oczekujących na transplantację nerki, wynikający z lęku przed rozpoczęciem aktywności, jest dodatkowo powodowany przez brak zaleceń ze strony personelu medycznego. Pacjenci nie otrzymują informacji na temat możliwości uczestniczenia w zajęciach ruchowych, ich intensywności czy wpływu na stan zdrowia. Na skutek licznych chorób współistniejących, których objawy są dodatkowo potęgowane przez brak ruchu, 
czują się osłabieni i zmęczeni. Taki stan zniechęca do podjęcia jakiejkolwiek aktywności. Z czasem chorzy zaczynają mieć problemy z wykonywaniem czynności dnia codziennego. Ciągłe zmęczenie i przewlekłe dolegliwości bólowe powodują, że w wielu przypadkach personel medyczny zaleca takim pacjentom prowadzenie oszczędzającego trybu życia. Takie postępowanie wtórnie doprowadza do zmniejszenia tolerancji wysiłku i wydolności fizycznej.

\section{PODSUMOWANIE}

Obserwowany jest stały rozwój metod leczenia pacjentów ze schyłkową niewydolnością nerek, wzrost liczby przeszczepień narządu oraz ciągły postęp badań nad poprawą funkcjonowania i komfortem życia osób po transplantacji. Nie udało się jednak do tej pory zniwelować ryzyka zgonu z powodu chorób współistniejących w tej grupie chorych. Główną przyczyną śmierci po zabiegu transplantacji nerki nie jest choroba podstawowa, a powikłania kardiologiczne. Wydaje się zasadnym wprowadzenie powszechnych zaleceń dotyczących aktywności fizycznej w tej populacji chorych. Badania przeprowadzone w Polsce i na świecie ukazują pozytywny wpływ programów rehabilitacyjnych w grupie osób z PChN. Jednak żadne z proponowanych działań nie zostało wprowadzone jako powszechne do programu leczenia.

\section{PIŚMIENNICTWO}

1. Lewandowska D, Hermanowicz M, Przygoda J, Podobińska J, Walczyk J. Krajowa lista oczekujących na przeszczepienie. Poltransplant 2014;1(22): 22-37.

2. Dąbrowski P, Olszanecka-Glinianowicz M, Chudek J. Żywienie w przewlekłej chorobie nerek. Endokrynol Otyłość 2011;7(4):229-37.

3. Rutkowski B. Wyprzedzające przeszczepienie nerek - najlepsza metoda leczenia nerkozastępczego. Przew Lek 2012;1:50-3.

4. Małyszko J. Przewlekła niewydolność nerek - problem tylko nefrologów? Chor Serca Naczyń 2005;2(2):78-83.

5. Gołębiowski T, Weyde W, Kusztal M, Szymczak M, Madziarska K, Penar J, et al. Ćwiczenia fizyczne w rehabilitacji chorych dializowanych. Postępy Hig Med Dośw (online) 2009;63:13-22.
6. Duława J, Ramos P. Rola wysiłku fizycznego w zapobieganiu chorobom układu sercowo-naczyniowego u chorych dializowanych. Probl Lek 2006,45(3):245-6.

7. Kunicki R. Nefrologia i leczenie nerkozastępcze. Praktyczny przewodnik. Gdańsk: Via Medica; 2013.

8. Durlik M, Klinger M. Chory dializowany jako biorca przeszczepu. Forum Nefrol 2010;3(3):201-11.

9. Walczyk J, Hermanowicz H, Antoszkiewicz K, Wysocka M, Przygoda J, Czerwiński J. Rejestr przeszczepień narządów. Poltransplant 2016;1(24):35-40.

10. Cichocka A, Lelonek M. Niewydolność serca po przeszczepie nerek część I. Epidemiologia, czynniki ryzyka, patomechanizmy. Folia Cardiol 2011;6(2):117-26.

11. Fazelzadeh A, Mehdizadeh MA, Raiss-Jalali GA. Predictors of cardiovascular events and associated mortality of kidney transplant recipients. Transplant Proc 2006;38(2):509-11. doi: 10.1016/j.transproceed.2006.02.004.

12. Stoumpos $S$, Jardine AG, Mark PB. Cardiovascular morbidity and mortality after kidney transplantation. Transpl Int 2015;28(1):10-21. doi.10.111/ tri.12413.

13. Mosconi G, Cuna V, Tonioli M, Totti V, Roi GS, Sarto P, et al. Physical activity in solid organ transplant recipients: preliminary results of the Italian project. Kidney Blood Press Res 2014;39(2-3):220-7. doi: 10.1159/000355800.

14. Krawczyk J, Wojciechowski J, Błaszczyk J, Błaszczyk-Suszyńska J. Wpływ treningu na stołach rehabilitacyjno-kondycyjnych na wybrane parametry gospodarki tłuszczowo-węglowodanowej. Pol Merkur Lekarski 2010;28(163):33-6.

15. Cupisti A, D’Alessandro C, Fumagalli G, Vigo V, Meola M, Cianchi C, et al. Nutrition and physical activity in CKD patients. Kidney Blood Press Res 2014;39(2-3):107-13. doi: 10.1159/000355784.

16. Chojak-Fijałka K, Smoleński O. Rehabilitacja ruchowa chorych przewlekle hemodializowanych - wyniki badań własnych. Now Lek 2005;45(3):247-56.

17. Van Heuvelen MJ, Kempen GI, Brouwer WH, de Geef MH. Physical fitness related to disability in older persons. Gerontology 2000;46(6):333-41.

18. Reimer J, Franke GH, Lutkes P, Kohle M, Gerken G, Philipp T, et al. Quality of life in patients before and after kidney transplantation. Psychotother Psychosom Med Psychol 2002;52(1):16-23. doi: 10.1055/s-2002-19662.

19. Lentine KL, Rocca-Rey LA, Bacchi G, Wasi N, Schmitz L, Salvalaggio PR, et al. Obesity and cardiac risk after kidney transplantation: experience at one center and comprehensive literature review. Transplantation 2008;86(2):303-12. doi: 10.1097/TP.0b013e31817ef0f9.

20. Segev DL, Simpkins CE, Thompson RE, Locke JE, Warren DS, Montgomery RA. Obesity impact access to kidney transplantation. J Am Soc Nephrol 2008;19(2):349-55. doi: 10.1681/ASN.2007050610.

21. Korabiewska I, Lewandowska M, Białoszewski D, Juskowska J. Zastosowanie ćwiczeń usprawniających w procesie leczenia nerkozastępczego przeszczepem alogenicznej nerki. Baln Pol 2008;1(111):35-41.

22. Chrobak M. Ocena jakości życia zależnej od stanu zdrowia. Probl Pielęg 2009;17(2):123-7.

23. Painter PL, Hector L, Ray K, Lynes L, Dibble S, Paul SM, et al. A randomized trial of exercise training after renal transplantation. Transplantation 2002;74(1):42-8 